\title{
Antiretroviral changes during the first year of therapy
}

\author{
Antonio Carlos Policarpo Carmo Sá Bandeira ${ }^{1 *}$, Darcielle Bruna Dias Elias ${ }^{2}$, Malena Gadelha Cavalcante $^{3}$, \\ Denise Girão Limaverde Lima ${ }^{4}$, Lara Gurgel Fernandes Távora ${ }^{5}$ \\ ${ }^{1}$ Pharmacist, Resident in Infectology, Escola de Saúde Pública do Ceará (ESP-CE), Hospital São José de Doenças Infecciosas (HSJ), Fortaleza, CE, Brazil \\ ${ }^{2} \mathrm{PhD}$ in Drug Development and Technological Innovation, Universidade Federal do Ceará (UFC). Managing Pharmacist, HSJ Laboratory, Fortaleza, CE, Brazil. \\ ${ }^{3}$ MSc in Medical Sciences, UFC. Pharmacist, Centro de Farmácia (CENFAR), HSJ, Fortaleza, CE, Brazil \\ ${ }^{4}$ Specialist in Hospital Pharmacy, ESP-CE. Pharmacist, CENFAR, HSJ, Fortaleza, CE, Brazil \\ ${ }_{5}^{5} \mathrm{PhD}$ in Infectious and Parasitic Diseases, Universidade de São Paulo (USP). MD, HSJ, Fortaleza, CE, Brazil
}

Study conducted at Escola de Saúde Pública do Ceará (ESP-CE), Hospital São José de Doenças Infecciosas (HSJ),

Fortaleza, CE, Brazil

Article received: $12 / 20 / 2016$ Accepted for publication: $1 / 14 / 2017$

*Correspondence: Address: Rua Doutor Atualpa, 1.034 Fortaleza, CE - Brazil Postal code: 60321-070 carlopolicarpo@gmail.com

http://dx.doi.org/10.1590/1806-9282.63.07.606

\section{SUMMARY}

Introduction: The Brazilian HIV/AIDS management and treatment guideline (PCDT), published in 2013, recommends and standardizes the use of highly active antiretroviral therapy (HAART) in all adult patients, in spite of $\mathrm{LTCD}_{4}$ count. This study aimed to analyze the first year of HAART use in patients from a reference center on HIV/AIDS management in Fortaleza, Ceará.

Method: This descriptive study reviewed all prescription forms of antiretroviral regimens initiation and changes from January to July 2014. All antiretroviral regimen changes that occurred during the first year of therapy were evaluated. Data were analyzed with SPSS version 20. Mean, standard deviation and frequency, Student's $t$ and Mann-Whitney tests calculations were used, with significance at $\mathrm{p}<0.05$.

Results: From 527 patients initiating HAART, 16.5\% $(\mathrm{n}=87)$ had a regimen change in the first year. These patients were mostly male $(59.8 \% ; n=52)$, aged 20 to 39 years, with only one HAART change $(72.4 \%$; $=63)$. Efavirenz was the most often changed drug, followed by tenofovir, zidovudine and lopinavir/ritonavir. Mean time of HAART changes was 120 days, with adverse reactions as the most prevalent cause. HAART was effective in decreasing viral load since second month of treatment $(\mathrm{p}=0.003)$ and increasing $\mathrm{LTCD}_{4}$ lymphocytes since fifth month $(\mathrm{p}<0.001)$.

Conclusion: The main cause of initial HAART changes was adverse reaction and most patients had only one change in the HAART regimen. HAART prescription was in accordance to the PCDT from 2013.

Keywords: acquired immunodeficiency syndrome, highly active antiretroviral therapy, human immunodeficiency virus.

\section{INTRODUCTION}

Human immunodeficiency virus (HIV) infection spreads to lymphoid tissues and follows initial course with high viremia and immune response, followed by seroconversion and, with replication and elevation in viral load (VL), $\mathrm{CD}_{4}{ }^{+}$ T lymphocytes $\left(\mathrm{LTCD}_{4}\right)$ are destroyed. ${ }^{1}$ After a few years, the symptomatic phase of the disease is established, with immunodeficiency and the appearance of coinfections. ${ }^{2,3}$

The Brazilian Ministry of Health recommends 19 drugs for HIV treatment. These drugs are divided into classes, according to their mechanisms of action, namely: nucleoside and nucleotide reverse transcriptase inhibitors (NRTIs), non-nucleoside analogue reverse transcriptase inhibitors (NNRTIs), protease inhibitors (PIs), fusion inhibitors, integrase inhibitors and entry inhibitors (CCR5 co-receptor antagonists). ${ }^{4,5,8}$

The introduction of the highly active antiretroviral therapy (HAART) in people living with HIV/AIDS (PLWHA) led to decreases in VL and increases in $\mathrm{LTCD}_{4}$, thus reducing hospitalizations and HIV transmission. Laboratory tests for $\mathrm{LTCD}_{4}$ and VL counts should be done during the use and change of HAART to verify the immuno-viral effectiveness of the treatment. ${ }^{6,7}$

The Brazilian HIV/AIDS management and treatment guideline (PCDT) recommends introduction of HAART in any $\mathrm{LTCD}_{4}$ count, followed by first-line regimens with combinations of two NRTIs associated with a NNRTI and second-line combinations with two NRTIs plus ritonavir- 
-boosted PI (PI/r), in cases of viral resistance, intolerance or toxicity with efavirenz (EFZ) or nevirapine (NVP). ${ }^{8}$ If VL remains detectable after six months of initiation or modification of HAART, virological failure may occur, with risk of disease progression, accumulation of antiretroviral (ARV) drug resistance mutations, and less robust and durable elevation of $\mathrm{LTCD}_{4}$ count, i.e., therapeutic failure.,

In clinical practice, antiretroviral regimens may be changed due to therapeutic failure but also on account of adhesion difficulties, complexity of HAART, and other pharmacological factors (adverse reactions, drug interactions and toxicity). ${ }^{1,9}$

At the São José Hospital for Infectious Diseases (HSJ-CE), approximately 3,944 PLWHA are assisted for treatment with HAART according to PCDT recommendations of 2013. Due to the increasing number of PLWHA using HAART, treatment monitoring for the rational adherence of patients to therapy has become a priority, with improved clinical parameters and less risk of failure, hospitalization, costs, morbidity and mortality, longer survival and positive prevention with the adoption of healthy lifestyle habits. ${ }^{8-10}$

In this context, we aimed to describe the profile of HIV+ patients seen at a reference center in Fortaleza/Ceará, who had their initial antiretroviral regimen modified in the first year of treatment, and the factors involved in the modifications of HAART during this period.

\section{Method}

This exploratory, descriptive and retrospective study was performed at the HSJ Pharmacy Center (CENFAR). Application forms for treatment initiation and modification of all outpatients who started HAART between January and July 2014 and who changed therapies during the first year of treatment were analyzed sequentially. These patients were followed for a period of one year after initiation of HAART. ${ }^{1}$

Patients using HAART for prophylaxis, followed in the private health network, in transit from other Brazilian states, pregnant women and children (under 18 years of age) were excluded from the study.

Data were collected from the Medication Logistics Control System (SICLOM), specific forms to justify treatment switch and patient records.

Data regarding patient identification, symptoms, drugs used, $\mathrm{LTCD}_{4}$ counts and VL, reason for the request to change the therapy, and the new requested scheme were amassed.

The analyses were performed using Statistical Package for the Social Sciences (SPSS) software version 20.

Statistical analysis included calculations of means, standard deviation and frequencies. The evolution of numerical variables was analyzed by Student's t-test for those with a normal distribution. For the others, Mann-Whitney test was used. P-value $<0.05$ was considered statistically significant. ${ }^{11}$

The study was approved by the Research Ethics Committee of HSJ, with Opinion No. 1,142,439 (Original Project).

\section{Results}

After we screened 527 patients who started HAART between January and July 2014, 120 were excluded because they were under medical supervision in the private health network, 11 children, three pregnant women and 306 patients who remained with initial HAART during the first year of treatment. The remaining 87 patients comprised our sample, being the $\mathrm{N}$ of the study.

Of these 87 patients, $59.8 \%(n=52)$ were male. The predominant age group was $20-39$ years (57.5\%), followed by $33.3 \%$ of patients aged $40-59$ years, and $6.9 \%$ over 60 years, most of them from the capital of the state of Ceará (59.8\%).

Coinfections were reported by $89 \%(n=77)$ of the patients, with one coinfection described in $17 \%(n=15)$, two coinfections in $31 \%(n=27)$, three coinfections in $20 \%$, and more than three coinfections in $21 \%(n=18)$. The most frequent coinfections were cytomegalovirus (25\%), toxoplasmosis $(21 \%)$, syphilis (12\%), tuberculosis (11\%), herpes simplex (6\%), histoplasmosis (6\%), candidiasis $(5 \%)$ and pneumocystis (5\%). AIDS was diagnosed in $64.4 \%$ of the patients $(\mathrm{n}=56)$.

The $\mathrm{LTCD}_{4}$ count and VL profile over the course of the treatment is shown in Chart 1 . The increase in $\mathrm{LTCD}_{4}$ counts was significant from 5 to 8 months of treatment $(\mathrm{p}<0.001)$. This increase was significant both in patients who had $\mathrm{LTCD}_{4}>500$ cells/dL and in those with > 200 cells/dL at the beginning of treatment. The decrease in $\mathrm{VL}$, in turn, was significant earlier, with 2 to 4 months of HAART $(\mathrm{p}=0.003)$.

Initial HAART with two NRTIs combined with one NNRTI was observed in $77 \%(n=67)$ of patients, especially the combination of tenofovir (TDF) + lamivudine $(3 T C)+E F Z$, present in $46 \%(n=40)$ of the forms. Another widely used regimen was the association zidovudine $(A Z T)+3 T C+E F Z$, present in the forms of $24 \%(n=21)$ of the patients.

Initial regimens presenting two NRTIs associated with one $\mathrm{PI} / \mathrm{r}$ were observed in the forms of $20 \%(\mathrm{n}=17)$ of the patients, with the following associations predominating: $\mathrm{TDF}+3 \mathrm{TC}$ with lopinavir $(\mathrm{LPV} / \mathrm{r})$, used by $8 \%(\mathrm{n}=7)$ of patients; and AZT + 3TC + LPV/r, used by $7 \%(\mathrm{n}=6)$. Analyzing each drug individually, we observed that the most used NRTI was 3 TC, present in $100 \%(n=87)$ of the regimens, 


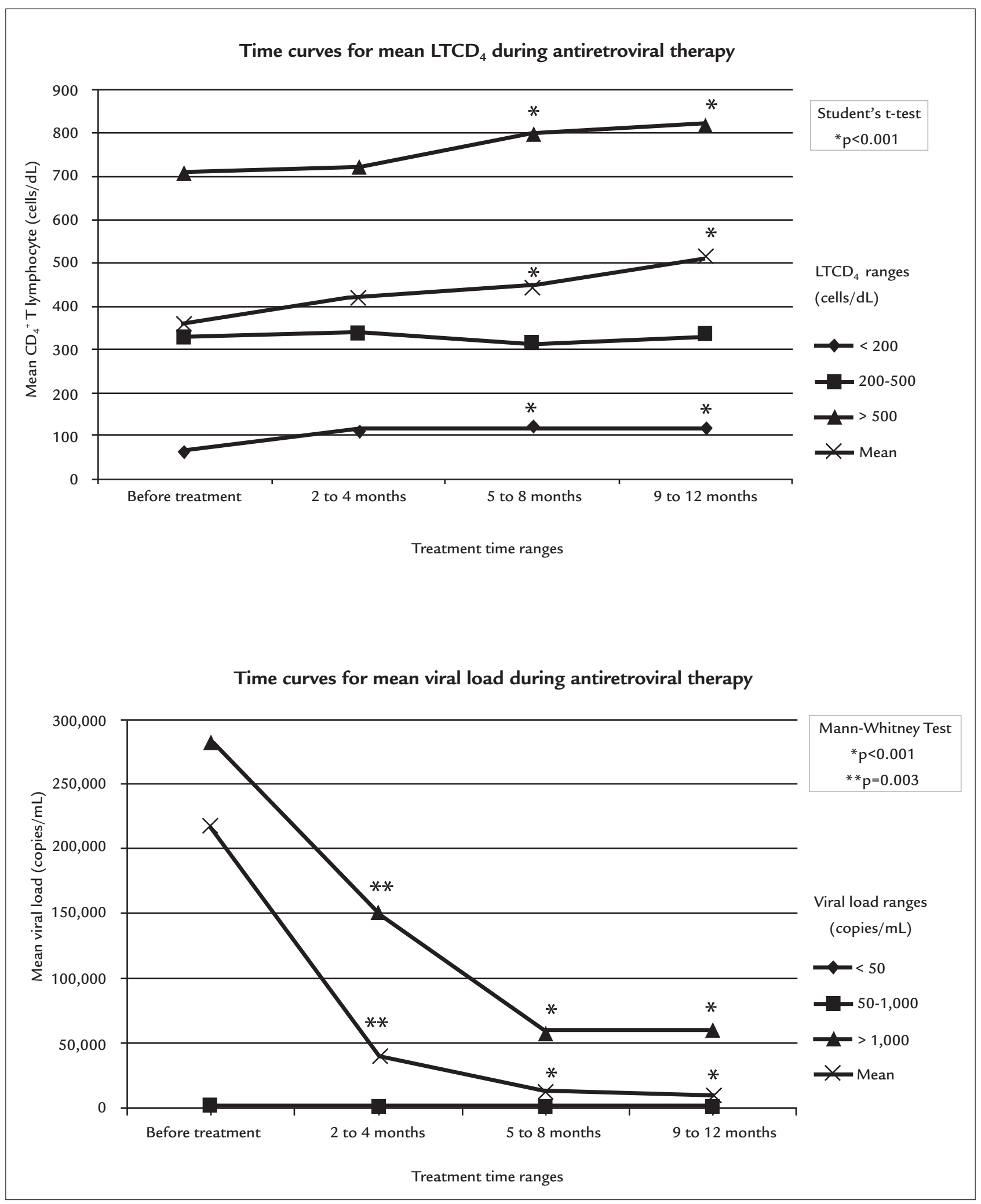

CHART 1 Time curves for mean $\mathrm{LTCD}_{4}$ counts and viral load during antiretroviral therapy. $p$-value or level of significance equal to $0.05, p=0.05$.

Source: Medication Logistics Control System (SICLOM) and medical records of the São José Hospital outpatient clinic. 
followed by TDF, in $62 \%(n=54)$. LPV/r was the most used $\mathrm{PI} / \mathrm{r}$, present in $17 \%(\mathrm{n}=15)$, followed by atazanavir $(\mathrm{ATV}) / \mathrm{r}$, found in $5 \%(n=4)$. In the NNRTI category, EFZ was the drug of choice, being present in $71 \%(n=62)$ of the regimens, followed by NVP in $6 \%(n=5)$ (Table 1$)$.

Of the 87 patients, $72.4 \%(\mathrm{n}=63)$ underwent one treatment switch, $21.8 \%(\mathrm{n}=19)$ two switches, $3.4 \%(\mathrm{n}=3)$ three switches, and $2.3 \%(n=2)$ four switches. In $79 \%(n=69)$ of the treatment switches only one drug was changed, whereas in $15 \%(n=13)$ two drugs were changed. Three drugs were switched in $3 \%(n=3)$ of the patients, and in $2 \%(n=2)$ there was a request to add a fourth drug, ATV $/ \mathrm{r}$ or raltegravir (RAL).

Adverse drug reactions (ADRs) were the main reasons for switching drugs of the initial HAART and were re- ported as a justification in $70.5 \%(\mathrm{n}=74)$ of the changes. Therapeutic failure was the reason for drug switching in 11 patients (12.6\%) (Table 2).

Of the 54 patients that started HAART with TDF (62.06\%, 54/87), 40.7\% ( $\mathrm{n}=22$ ) switched medications, $68.2 \%$ $(\mathrm{n}=15)$ due to kidney dysfunction or nephrotoxicity. Of the 62 patients who used initial EFZ (71.26\%, 62/87), 67.74\% $(\mathrm{n}=42)$ switched the drug, $35.7 \%(\mathrm{n}=15)$ for psychological reactions and $26.2 \%(\mathrm{n}=11)$ due to hypersensitivity reactions. $\mathrm{LPV} / \mathrm{r}$ was associated with drug switching in $47 \%(\mathrm{n}=7)$ of 15 initial regimens in which it was present, mainly due to gastrointestinal reactions. Table 2 shows the motives for switching drugs and the drugs replaced in the initial schemes.

The only drug that was not changed in the initial HAART was 3TC. Among NRTIs, TDF was replaced 22

TABLE 1 Profile of frequency of use of drugs in initial and modified antiretroviral therapy.

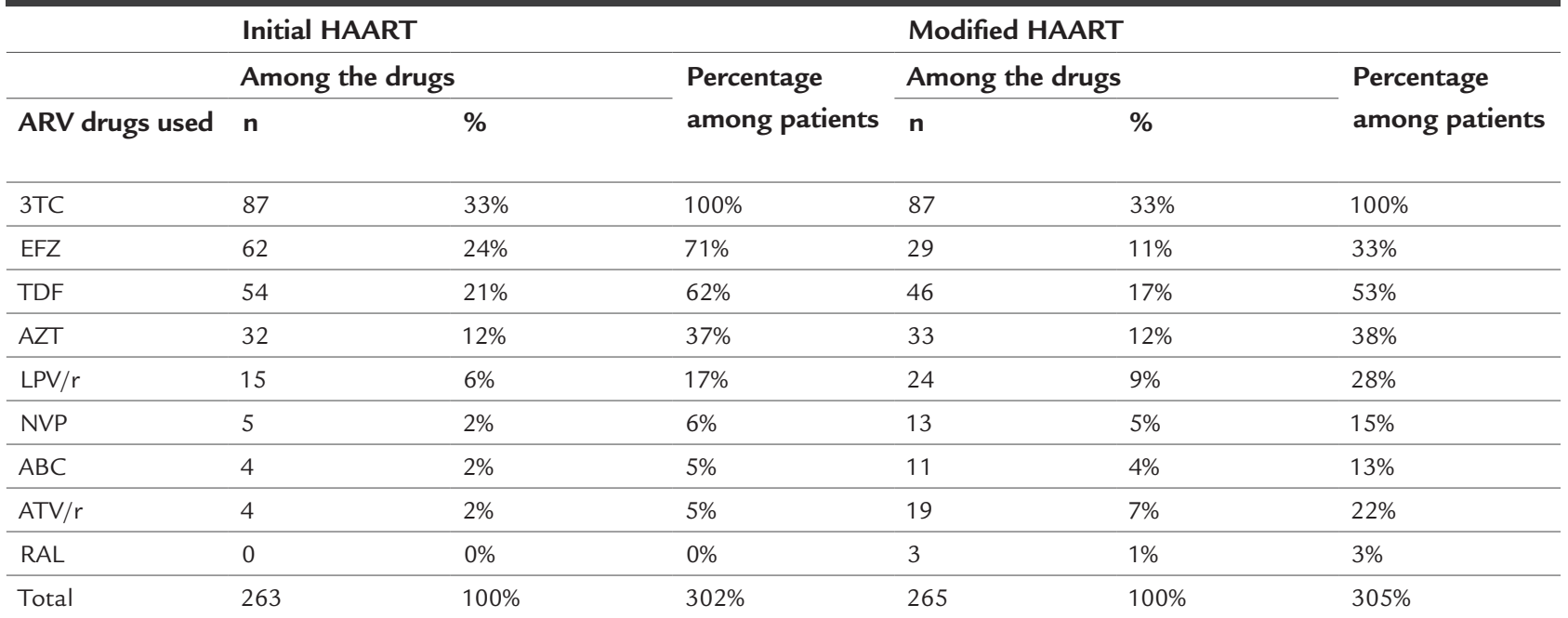

HAART: highly active antiretroviral therapy; ARV: antiretroviral; n: number of times the drug was used; \%: percentage; 3TC: lamivudine; EFZ: efavirenz; TDF: tenofovir; AZT: zidovudine; LPV: lopinavir; r: ritonavir; NVP: nevirapine; ABC: abacavir; ATV: atazanavir; RAL: raltegravir.

Source: Medication Logistics Control System (SICLOM) and HAART switch request forms

TABLE 2 Association between the reasons for switching and drugs switched in the initial schemes.

\begin{tabular}{|c|c|c|c|c|c|c|c|c|}
\hline \multirow[b]{2}{*}{ Reason for switching } & \multicolumn{8}{|c|}{ Drugs switched } \\
\hline & $\begin{array}{l}\mathrm{LPV} / \mathrm{r} \\
\mathrm{n}(\%)\end{array}$ & $\begin{array}{l}A Z T \\
n(\%)\end{array}$ & $\begin{array}{l}\text { EFZ } \\
n(\%)\end{array}$ & $\begin{array}{l}\text { TDF } \\
\text { n (\%) }\end{array}$ & $\begin{array}{l}\text { NVP } \\
\text { n (\%) }\end{array}$ & $\begin{array}{l}\text { ATV/r } \\
\text { n (\%) }\end{array}$ & $\begin{array}{l}A B C \\
n(\%)\end{array}$ & $\begin{array}{l}\text { Total } \\
\text { n (\%) }\end{array}$ \\
\hline Gastrointestinal reactions & $6(35)$ & $2(12)$ & $4(24)$ & $2(12)$ & $1(6)$ & $2(12)$ & & $17(100)$ \\
\hline Psychological reactions & & & $15(100)$ & & & & & $15(100)$ \\
\hline Hypersensitivity & & $3(20)$ & $11(73)$ & & $1(7)$ & & & $15(100)$ \\
\hline Kidney dysfunction & & & $2(11)$ & $15(83)$ & & $1(6)$ & & $18(100)$ \\
\hline Myelotoxicity & & $5(100)$ & & & & & & $5(100)$ \\
\hline Liver dysfunction & & & & & $1(100)$ & & & $1(100)$ \\
\hline Drug interaction & & & $6(100)$ & & & & & $6(100)$ \\
\hline Dose optimization & $1(10)$ & $5(50)$ & & & $1(10)$ & $1(10)$ & $2(20)$ & $10(100)$ \\
\hline Genotyping/Rescue & & & $4(36)$ & $5(45)$ & $2(18)$ & & & $11(100)$ \\
\hline
\end{tabular}

n: number of times the drug was switched; \%: percentage; 3TC: lamivudine; EFZ: efavirenz; TDF: tenofovir; AZT: zidovudine; LPV: lopinavir; r: ritonavir; NVP: nevirapine; ABC: abacavir; ATV: atazanavir. Source: Medication Logistics Control System (SICLOM), HAART switch request forms and medical records of the São José Hospital outpatient clinic. 
times, $64 \%(n=14)$ by AZT and $36 \%(n=8)$ by abacavir (ABC). As for the NNRTIs, EFZ was replaced 42 times, $40 \%(n=17)$ by ATV/r and 33\% $(\mathrm{n}=14)$ by LVP/r. Among the PI/r, LPV/r was replaced seven times, $71 \%(\mathrm{n}=5)$ by EFZ.

The initial regimens had an average duration of 100.6 days ( \pm 93.4 ), ranging between 1 and 330 days of treatment. Schemes with 2 NRTI +1 NNRTI had an average duration of 102 days ( \pm 97.6$)$, being mainly represented by the $\mathrm{TDF}+3 \mathrm{TC}+\mathrm{EFZ}$ scheme. Combinations with $2 \mathrm{NRTI}+1$ $\mathrm{PI} / \mathrm{r}$ lasted shorter, with a mean duration of 94 days $( \pm 75.7)$, being more often represented by TDF $+3 \mathrm{TC}+\mathrm{LPV} / \mathrm{r}$ and $\mathrm{TDF}+3 \mathrm{TC}+\mathrm{ATV} / \mathrm{r}$.

\section{Discussion}

In our study, the prevalence of male patients was evident, which seems to be in agreement with data in the literature. In recent years, there has been an increase in the number of men with HIV. ${ }^{12}$ As of 2009, there was a decline in the number of AIDS cases in women and an increase in men, yielding a sex ratio that in 2014 was 19 cases of AIDS in men for every ten cases in women according to the Epidemiological Bulletin on HIV/AIDS Surveillance (2015).${ }^{13}$ Studies in Spain, Italy, the United States and India also point to an increasing prevalence of HIV infection among men. ${ }^{14-18}$

AIDS was diagnosed in $64.4 \%$ of the patients, which can be explained by problems of adherence to HAART and/or late treatment start, according with $\mathrm{LTCD}_{4}$ count and VL profile, which makes immune reconstitution and viral suppression more difficult with onset of resistance, directly reflecting the appearance of AIDS coinfections and symptoms in 15 to $61 \%$ of patients. ${ }^{7,19-22}$

In the 87 patients studied, $\mathrm{LTCD}_{4}$ increase was significant between the fifth and eighth month of treatment. In most individuals, the onset of HAART is accompanied by higher $\mathrm{LTCD}_{4}$ counts and immune recovery. Usually, this occurs in the first year of treatment. Then, stability is observed, followed by improvement in the second year. ${ }^{4,8}$ However, in spite of a significant increase in $\mathrm{LTCD}_{4}$ counts in our sample, even in patients who initiated HAART with levels lower than 200 cells/dL, in some patients this increase was not enough to reverse the state of severe immunosuppression. This finding may signal adhesion problems ${ }^{19-21}$ or partial immunological reconstitution in patients with low initial $\mathrm{LTCD}_{4}$ counts. ${ }^{6,16,20}$ This situation occurs due to late onset of HAART in immunocompromised patients, so that initially low levels of $\mathrm{LTCD}_{4}$ are important predictors of the suboptimal recovery response of $\mathrm{LTCD}_{4} \cdot{ }^{23,24}$

Effectiveness of HAART on the decrease in VL from the start of treatment ( 2 to 4 months) was evidenced, with the majority of patients reaching undetectable levels be- tween the fifth and eighth month. Patients who started treatment with VL greater than 1,000 copies/mL had partial viral suppression, since they did not reach undetectable VL six months after starting treatment. However, this does not mean virologic failure, since most HAART changes in these patients occurred before the first six months of treatment. Studies show that about $80 \%$ of patients achieve plasma VLs of less than 50 copies $/ \mathrm{mL}$ after one year of treatment and that viral suppression is maintained over time, whereas virological failure may be characterized with VL counts higher than 50 copies/mL after six months of treatment without interruptions or changes. ${ }^{4,6-8}$

Most of the initial regimens used in this population consisted of $2 \mathrm{NRTI}+1 \mathrm{NNRTI}$, followed by $2 \mathrm{NRTI}+1 \mathrm{PI} / \mathrm{r}$, with TDF + 3TC + EFZ and TDF + 3TC + LPV/r as the predominant associations in each case, respectively. These findings are in agreement with the 2013 PCDT recommendations. ${ }^{8}$

In most of the initial HAART switches studied, only one drug was replaced in the scheme. Studies indicate that changes within six months usually occur because of intolerance or toxicity. ${ }^{14,15,25,26}$ The fact that most of the treatment switches in the present study involved only one drug can be explained by the occurrence of ADR to a specific drug in the scheme in most of the cases (70\%).

Among the ADRs presented, gastrointestinal reactions were more often associated with $\mathrm{LPV} / \mathrm{r}$, while psychological reactions and hypersensitivity were associated with EFZ, renal alteration with TDF, myelotoxicity with AZT, and hepatic alteration with NVP. These data are in agreement with results obtained by several authors, which show similar correlations between the antiretroviral drugs and their main clinical and laboratory alterations. ${ }^{14,15,17,25-27}$

Other studies also reveal that changes in HAART after six months may also occur after confirmation of immuno-virological failure and low adherence. ${ }^{16,17,19-21} \mathrm{In}$ our population, therapeutic failure, although not the most prevalent cause for HAART replacement, was the reason for switching drugs in $12.6 \%$ of the cases that used initial TDF $+3 \mathrm{TC}+\mathrm{EFZ}$ and $\mathrm{AZT}+3 \mathrm{TC}+\mathrm{EFZ}$ regimens. Other authors showed that TDF $+3 \mathrm{TC}+\mathrm{EFZ}$ schemes resulted in viral suppression in $92 \%$ of patients and virological failure in 8 and $10.8 \%$ of patients. ${ }^{7,22}$ Initial regimens with emtricitabine (FTC) + TDF + EFZ had a $3.6 \%$ failure. ${ }^{22}$ In one study ${ }^{21}$ virological failure combined with viral resistance occurred in $24.1 \%$ of patients with interruption and resumption of treatment using stavudine $(\mathrm{d} 4 \mathrm{~T})+3 \mathrm{TC}+\mathrm{NVP}, \mathrm{d} 4 \mathrm{~T}+3 \mathrm{TC}+\mathrm{EFZ}$ and $\mathrm{AZT}+3 \mathrm{TC}+$ $\mathrm{NVP}$ regimens. Other studies showed that $\mathrm{d} 4 \mathrm{~T}$ regimens had virological failure in $16.9 \%$, motivated by predictors such as treatment interruptions, use of NVP, initial LTCD $_{4}$ 
$<25$ cells/dL, initial VL $\geq 400$ copies/mL, and stage of AIDS, ${ }^{14,16,17,19,20}$ while only 7.7 and $2.65 \%$ obtained treatment failure with the same regimens in other studies. ${ }^{18,25}$ These differences may be justified by factors such as ARV classes (NRTI, NNRTI and PI), adherence, toxicity, adverse reactions, incorrect drug combinations in coinfections, and pharmacogenetics of patients. ${ }^{4,6,10,15,26}$

In our study, EFZ was the drug most often switched in the initial regimens. This is possibly due to the significant prevalence of CNS-related adverse events associated with this drug. ${ }^{4,6,15}$ It should also be noted that EFZ was one of the most prescribed drugs, since it is part of the preferential scheme for the initiation of HAART in Brazil, ${ }^{8}$ which may also have led to a higher prevalence of switching of this drug.

In patients who had to change EFZ, the main drugs of choice were ATV/r and LPV/r. In those who switched TDF, most did so for AZT, followed by ABC. These changes were in accordance with the recommendations of the 2013 PCDT. 8

The authors identified limitations in the present study. The instruments used for data collection (HAART switch request form, SICLOM drug dispensing record, incomplete laboratory data), together with the retrospective design of the study, have led to difficulties in the analysis of adherence to follow-up and treatment.

\section{Conclusion}

The epidemiological profile of patients undergoing changes in initial HAART revealed the prevalence of men in the age group between 20 and 39 years.

The use of HAART led to an immuno-virological response with a significant increase in the mean $\mathrm{LTCD}_{4}$ count and a significant reduction in the mean $\mathrm{VL}$, the former having a later effect when compared to the latter.

The main schemes used to initiate therapy were composed of 2 NRTI + 1 NNRTI. EFZ was most often used in early therapies compared to LPV/r and ATV/r; however, it was also the most often switched drug.

ADRs were the most frequent cause of HAART replacement, most of the times requiring the replacement of only one of the drugs in the initial regimen.

\section{Resumo}

Mudanças de terapia antirretroviral durante o primeiro ano de tratamento

Introdução: O Protocolo Clínico e Diretrizes Terapêuticas para manejo da infecção pelo HIV em adultos (PCDT) de 2013 recomenda e normatiza início de terapia antirretroviral (TARV) em pacientes com qualquer contagem de $\mathrm{LTCD}_{4}$. O objetivo do estudo foi analisar o primeiro ano de TARV de pacientes em acompanhamento em um centro de referência em HIV/AIDS de Fortaleza, Ceará.

Método: $\mathrm{O}$ estudo descritivo revisou formulários de solicitação de início e modificação de TARV em pacientes que iniciaram tratamento entre janeiro e julho de 2014. Foram avaliadas todas as mudanças que ocorreram durante o primeiro ano de terapia. Os dados foram analisados no programa Statistical Package for the Social Sciences (SPSS) versão 20. Foram calculados médias, desvios padrão, frequências, testes t Student e Mann-Whitney, com significância de $\mathrm{p}<0,05$.

Resultados: Dos 527 pacientes que iniciaram TARV, 16,5\% $(\mathrm{n}=87)$ realizaram troca no primeiro ano. A maioria era do sexo masculino (59,8\%; $\mathrm{n}=52)$, de 20 a 39 anos, com apenas uma mudança da TARV $(72,4 \% ; n=63)$. Efavirenz foi o fármaco mais substituído, seguido por tenofovir, zidovudina e lopinavir/ritonavir. O tempo médio de ocorrência das modificações da TARV foi de 120 dias, tendo reações adversas como causas principais. TARV foi efetiva na queda da carga viral desde o $2^{\circ}$ mês de tratamento $(\mathrm{p}=0,003)$ e na elevação de $\mathrm{LTCD}_{4}$ desde o $5^{\circ}$ mês $(\mathrm{p}<0,001)$.

Conclusão: Os principais fatores envolvidos em modificações de TARV inicial foram reações adversas, com apenas uma mudança de esquema na maioria dos pacientes. O manejo da TARV estava de acordo com o PCDT de 2013.

Palavras-chave: síndrome da imunodeficiência adquirida, terapia antirretroviral de alta atividade, vírus da imunodeficiência humana.

\section{REFERENCES}

1. Lima DGL, Arruda EAG, Lima AJA, Oliveira BE, Fonteles MMF. Fatores determinantes para modificações da terapia antirretroviral inicial. Rev Assoc Med Bras. 2012; 58(2):222-8.

2. Ferreira AW, Moraes SL. Diagnóstico laboratorial das principais doenças infecciosas e autoimunes. 3. ed. Rio de Janeiro: Guanabara Koogan; 2013.

3. Rodrigues-Júnior AL, Castilho EA. AIDS e doenças oportunistas transmissíveis na faixa de fronteira brasileira. Rev Soc Bras Med Trop. 2010; 43(5):542-7.

4. Günthard HF, Aberg JA, Eron JJ, Hoy JF, Telenti A, Benson CA, et al.; International Antiviral Society-USA Panel. Antiretroviral treatment of adult HIV infection: 2014 recommendations of the International Antiviral SocietyUSA Panel. JAMA. 2014; 312(4):410-425.

5. Tang MW, Shafer RW. HIV-1 antiretroviral resistance: scientific principles and clinical applications. Drugs. 2012; 72(9):e1-e25.

6. Ryom L, Boesecke C, Gisler V, Manzardo C, Rockstroh, JK, Puoti M, et al.; EACS Governing Board. Essentials from the 2015 European AIDS Clinical Society (EACS) guidelines for the treatment of adult HIV-positive persons. HIV Med. 2015; 17(2):83-8.

7. Amoroso A, Etienne-Mesubi M, Edozien A, Ojoo S, Sheneberger R, Obiefune $\mathrm{M}$, et al. Treatment outcomes of recommended first-line antiretroviral regimens in resource-limited clinics. J Acquir Immune Defic Syndr. 2012; 60(3):314-20. 
8. Ministério da Saúde. Protocolo clínico e diretrizes terapêuticas para manejo da infecção pelo HIV em adultos. 8. ed. Brasília: Secretaria de Vigilância em Saúde; 2013.

9. Saberi P, Dong BJ, Johnson MO, Greenblat RM, Cocohoba JM. The impact of HIV clinical pharmacists on HIV treatment outcomes: a systematic review. Patient Prefer Adherence. 2012; 6:297-322.

10. Carcelero E, Tuset M, Martin M, Lazzari E, Codina C, Miró J, et al. Evaluation of antirretroviral-related errors and interventions by the clinical pharmacist in hospitalized HIV-infected patients. HIV Med. 2011; 12(8):494-9.

11. Pereira MG. Artigos científicos: como redigir, publicar e avaliar. Rio de Janeiro: Guanabara Koogan; 2014.

12. Rossi SMG, Maluf ECP, Carvalho DS, Ribeiro CEL, Battaglin CRP. Impacto da terapia antirretroviral conforme diferentes consensos de tratamento da AIDS no Brasil. Rev Panam Salud Publica. 2012; 32(2):117-23.

13. Ministério da Saúde. Taxa de detecção de aids (por 100 mil habitantes) segundo sexo e razão de sexos por ano de diagnóstico. Brasil, 2005 a 2014. Gráfico 5. Bol Epidemiol HIV/AIDS 2014/2015; 4(1):11 [cited 2016 Oct 13] Available from: http://www.aids.gov.br/sites/default/files/anexos/ publicacao/2015/58534/boletim_aids_11_2015_web_pdf_19105.pdf.

14. Jarrin I, Hernández-Novoa B, Alejos B, Riera M, Navarro G, Bernardino JI, et al. Persistence of novel first-line antirretroviral regimes in a cohort of HIVpositive subjects, CoRIS 2008-2010. Antiviral Ther. 2013; 18(2):161-70.

15. Prosperi MCF, Fabbiani M, Fanti I, Zaccarelli M, Colafigli M, Mondi A, et al. Predictors of first-line antirretroviral therapy discontinuation due to drug-related adverse events in HIV-infected patients: a retrospective cohort study. BMC Infect Dis. 2012; 12:296.

16. Marconi VC, Grandits GA, Weintrob AC, Chun H, Landrum ML, Ganesan A, et al.; Infectious Disease Clinical Research Program HIV Working Group (IDCRP). Outcomes of highly active antiretroviral therapy in the context of universal access to healthcare: the U.S. Millitary HIV Natural History Study. AIDS Res Ther. 2010; 7:14

17. Cicconi P, Cozzi-Lepri A, Trecarichi EM, Antinori A, Gatti F, et al.; ICoNA Foundation Study Group. Insights into reasons for discontinuation according to year of starting first regimen of highly active antiretroviral therapy in a cohort of antiretroviral-naïve patients. HIV Med. 2010; 11(2):104-13.

18. Sivadasan A, Abraham OC, Rupali P, Pulimood AS, Rajan J, Rajkumar S, et al. High rates of regimen change due to drug toxicity among a cohort of
South Indian adults with HIV infection initiated on generic, first-line antiretroviral treatment. J Assoc Physicians India. 2009; 57:384-8.

19. Zheng Y, Hughes MD, Lockman S, Benson CA, Hosseinipour MC, Campbell TB, et al. Antiretroviral therapy and efficacy after virologic failure on first-line boosted protease inhibitor regimens. Clin Infect Dis. 2014; 59(6):888-96.

20. Fox MP, Van Cutsem G, Giddy J, Maskew M, Keiser O, Prozesky H, et al. Rates and predictors of failure of first-line antiretroviral therapy and switch to second-line ART in South Africa. J Acquir Immune Defic Syndr. 2012; 60(4):428-37

21. Luebbert J, Tweya H, Phiri S, Chaweza T, Mwafilaso J, Hossenipour MC, et al. Virological failure and drug resistance in patients on antirretroviral therapy after treatment interruption in Lilongue, Malawi. Clin Infect Dis. 2012; 55(3):441-8.

22. Rokx C, Fibriani A, van de Vijver DAMC, Verbon A, Schutten M, Gras L, et al.; AIDS Therapy Evaluation in the Netherlands National Observational Cohort. Increased virological failure in naive HIV-1 infected patients taking lamivudine compared with emtricitabine in combination with tenofovir and efavirenz or nevirapine in the Dutch nationwide ATHENA cohort. Clin Infect Dis. 2014; 60(1):143-53.

23. Asmelash A, Zeng Y, Kaloustian KW, Shaffer D, Sawe F, Ogwu A, et al Predictors of suboptimal CD4 response among women achieving virologic supression in a randomized antiretroviral treatment trial, Africa. BMC Infectious Dis. 2014; 14:331.

24. Asfaw A, Ali D, Eticha T, Alemayehu A, Alemayehu, M, Kindeya F. CD4 cell count trends after commencement of antiretroviral therapy among HIVinfected patients in Tigray, Northern Ethiopia: a retrospective cross-sectional study. PloS One. 2015; 10(3):e0122583.

25. Woldemedhin B, Wabe NT. The reason for regimen change among HIV/ AIDS patients initiated on first line highly active antiretroviral therapy in Southern Ethiopia. North Am J Med Sci. 2012; 4(1):19-23.

26. Eluwa GI, Badru T, Agu KA, Akpoigbe KJ, Chabikuli O, Hamelmann C. Adverse drug reactions to antiretroviral therapy (ARVs): incidence, type and risk factors in Nigeria. BMC Clin Pharmacol. 2012; 12:7.

27. Kalyesubula R, Kagimu M, Opio KC, Kiguba R, Semitala CF, Schlech WF, et al. Hepatotoxicity from first line antiretroviral therapy: an experience from a resource limited setting. Afr Health Sci. 2011; 11(1):16-23. 